\title{
CALL and SLA Theory: Developing A Framework to Analyze Web-based Materials for Teaching Listening Skills
}

\author{
Khoiriyah Khoiriyah \\ *khoiriyah230693@umm.ac.id \\ Faculty of Teacher Training and Education, University of Muhammadiyah Malang, \\ Malang, Indonesia
}

Received: 7 April 2020 Accepted: 9 May 2020

DOI: $10.24256 /$ ideas.v8i1.1296

\begin{abstract}
Listening skills, considered by many to be the most critical language learning skills, have yet to emerge a variety of problems for learners. In order to have an effective listening class, teachers can use one of the many technology-enhanced language learning tools, web-based materials. In this article attempts have been made to make a comprehensive review on the grounded theory of Computer-Assisted Language Learning (CALL) and Second Language Learning (SLA) related to the use of web-based resources in teaching and learning English, especially for listening skills. This article also proposes a framework for conducting CALL evaluation that is worthy for website materials. The result yields a good guideline for teachers to make judgment or decision in choosing the most congruent web-based sources for teaching listening skills. As a result, teachers are able to adapt a proper teaching materials and methodology for listening skills.
\end{abstract}

Keywords: CALL, CALL Evaluation, SLA, web-based listening materials

\section{Introduction}

In learning English, listening is considered as the essential skills among other skills (speaking, reading and writing), but it involves a complex process. As listening is known as the most frustrating ability that ESL or EFL learners can master for the very first time, a number of problems have emerged (Al-azzemy \& Al-jamal, 2019; Aryanaa, Suhud \& Apasari, 2018; Du, 2019; Emerick, 2018). Take an example; learners are unable to regulate the aural input speed, which leads them to hear the sounds correctly. In other cases, even though the learners accurately capture the sounds, they sometimes experience some comprehension problems because they lack adequate knowledge of vocabulary, colloquial language 
or even slang language (Hamouda, 2013; Namaziandost et al., 2019; Vandergrift \& Goh, 2012). Thus, learners need language input as much as possible.

In addition, reflecting the common textbook for listening, Murray and McPherson (2004) Demissie (2019), Hanbi (2019) highlight that the design of textbook activities is primarily a product-oriented approach (more focused on testing the word recognition and listening comprehension of learners) rather than a method-oriented approach (providing instruction to allow learners to have a more successful method of recognizing words and understanding). Students receive little support from the textbook to efficiently understand a successful listening technique (Gilakjani \& Sabouri, 2016a; Hamouda, 2013; Pekel, 2019). Consequently, teachers have a vital role in the teaching and learning cycle in a classroom in order to create more efficient learning process by offering more profound insights into the capacity of learners, teaching how to listen effectively and encouraging them to listen more effectively.

Regardless of those limitations, the only effort teachers can do to enhance their students' listening skills is to incorporate the use of technology into the learning process (Gaber, 2015; Mohamed Fauzi \& Raja Hussain, 2016; Naely et al., 2012; Sukmawati \& Eka, 2018; Takaesu, 2013). Computer-Assisted Language Learning (CALL) technology should be integrated in the course or task, in addition to promoting language learning principles, when it makes teaching and learning more effective, more efficient, or both (Felix \& Felix, 2007; Golonka et al., 2014; Hellmich, 2019). Effective means that students use the technology to learn the language better or faster than they would have used the resources that would ordinarily be available. Meanwhile, efficient means that with less time and energy, technology helps teachers and students achieve the learning objectives.

To efficiently meet the principles for language learning with the principle of CALL and technology use, teachers can use any of the many technology-enhanced language learning (Egbert, 2018; Henrichsen et al., 2018; Xie, 2018). Therefore, teachers should make use of multimodal, media-based materials for their listening classroom (Milliner, 2018). One of which is the teaching tools based on the website. Nonetheless, teachers should verify whether they comply with guidelines for good language pedagogy. Students who learn language autonomously via CALL are required to be aware of how and why such language practices based on technology are better for their learning than others. Overall, the basic theory of second language learning and CALL indicate that the concepts of language learning will guide the use of technology in the language classroom effectively. Hence, this article explores CALL and SLA theory and proposes a framework as a basis to analyze the effectiveness of website-based resources to teach listening skills.

\section{CALL, SLA Theory and Listening Skills}

The basic components of Computer-Assisted Language Learning (CALL) and Second Language Acquisition (SLA) theory should be linked together to provide 
Khoiriyah Khoiriyah

CALL and SLA Theory: Developing A Framework to Analyze Web-based Materials for Teaching Listening Skills

good practices in language learning (Nunan, 1998; Tafazoli \& Golshan, 2014). To begin with, listening becomes the most important skill in the very early stage of the learning process based on the 'comprehensible input' theory of SLA promoted by (Krashen, 1984). Krashen stresses that understanding the input is the main purpose of language learning. The learning process happens as long as the learners can comprehend the message conveyed by the input. Hence listening plays a crucial role in language classroom, as it provides learners with language input. In fact, Krashen assumes that the productive skills (speaking and writing) proceeded from the receptive skills (listening and reading). Learners should be given more information on the understandable feedback in the classroom context (Gilakjani \& Sabouri, 2016). In the classroom context, learners should get more exposure on the comprehensible input. Learners are gain more opportunity not only to see and hear the language in use but also to use the target language.

In order to provide learners with comprehensible input, it is simply by providing them with understandable linguistic data either in oral or in written form. The more enormous amount of comprehensible input the learners are exposed to, the more opportunity the learners turn it into intake (Chao, 2013). Furthermore, Krashen in Beatty (2010) strongly emphasizes on:

In terms of CALL, Krashen describes optimal input for acquisition as having four characteristics: (1) it is comprehensible; (2) it is interesting and/or relevant to the acquirer; (3) it is not grammatically sequenced; (4) it is provided in sufficient quantity. CALL can generally deal with all of these criteria, including adding a wide range of extra-linguistic clues through sound, images, animation and video.

Further, supported by Krashen's theory, CALL materials along with its extra-linguistic features such as sound, images, animation and video generally meet with those criteria. As a result, those will be contributing to the process of learners' SLA. Using CALL materials, especially website materials with the authentic material, is basically providing a roughly tuned input. Different from a finely tuned input (modified input in order to meet learners' level of acquisition) the roughly tuned input is not structured or based on the learners' level of acquisition. Take an example, listening to a TV broadcast might lead learners to have difficulties in some new vocabularies, but it does not mean that learners cannot understand the input at all. The learners still understand the main idea of those input. This happens because some of the language structure (e.g. vocabulary and grammar) are slightly beyond the learners' level acquisition. Nonetheless, through previewing, practicing, and finally reviewing those input, learners will recognize those structure, get a better kind of input and their language seems more natural as well.

In line with this, Chapelle \& Hall (2009) summarizes some SLA approaches and its implementations for CALL based on four focuses including cognitive linguistic approaches, psycholinguistic approaches, general human learning and 
approaches to language in a social context. First, cognitive linguistics approach is basically related to Universal Grammar (UG), autonomous induction theory, and the concept-oriented approach. UG and autonomous induction theories explain a natural development of discovering the structural grammatical knowledge since CALL materials provide a basis for sequencing grammatical forms. Meanwhile, the concept-oriented approach describes how learners' figure out the form-meaning mapping based on the input. In a nutshell, sequenced instruction enables to boost the process of acquisition.

Second, due to the input processing, learners get involved in a psycholinguistics processing that allows them to turn input into intake. Based on the SLA theory in psycholinguistics perspective, the idea of CALL materials is linked with material development. Task should be designed to stimulate learners to link between form and meaning. Van Pattern (2007) argues that in processing the input, the learners are primarily attending to the meaning to comprehend the whole input so providing some additional exercises will definitely help learners to identify some certain aspects of input. Further, the interactionist theory looks at the possible interaction between computer and learners enabling them to enhance their comprehension through doing some activities such as doing additional exercises, requesting some help or hints in first language, having access on L2 glosses, grammar simplification, images and other kind of extra non-linguistics help, and receiving feedback from computer from their production.

Meanwhile, the theory of general human learning approach concludes that learning language is a part of practice; hence the task provides learners with the optimal amount to get exposure of the target language. The more opportunities the learners get, the greater the possibility they will be able to transform their declarative knowledge (e.g. grammar pattern) into procedural knowledge (e.g. how to use the grammar accurately in speaking) automatically. The last, other SLA approach is language in social context. The use of the Internet allows the learner to have peer interaction in using target language as well as to develop intercultural competence. In conclusion, those theoretical bases will be useful for either CALL design or CALL evaluation.

\section{CALL Software Evaluation}

As an attempt to evaluate CALL software, it involves a wide range of variables which is immensely impossible to control all of those relevant variables such as location, time, cultures, resources, teachers, pedagogical approaches, didactical strategies, intended learning outcomes, task brief and task outcomes. As a result, CALL software evaluation only can be done through evaluating all of those features carefully and systematically within deciding its limitations (Okonkwo, 2011).

In line with this, Hubbard (2006) articulates that CALL software evaluation is a process which includes three stages as follows; (1) selecting and judging the appropriateness of a CALL software as given helping tools in language learning 
CALL and SLA Theory: Developing A Framework to Analyze Web-based Materials for Teaching Listening Skills

setting; (2) identifying the effective ways of using CALL software in that setting; and (3) assessing how far CALL software helpful and adjusting whether continue to use it or not as well as making adjustment for future use. That systematic evaluation might better by considering the influence of CALL software usage on learning within three perspectives including software designers, teachers and learners (Soromic, 2010). In a nutshell, due to those different perspectives, the evaluator is able to decide in which particular context evaluation can be made either in proposed use (predictive evaluation) or actual use (interpretative evaluation).

Several researchers have addressed the criteria for assessing the CALL software. The most influential frameworks have been formulated by Chapelle (2001) and Hubbard (2006). Taking a look at the Chappelle's work, he proposed five criteria for evaluating the appropriateness of multimedia sources or websites sources namely: (1) Language learning potential. It reflects what extent the multimedia sources provide an opportunity for focusing on activity rather than having a chance only to be exposed to the target language; (2) Learner fit. It considers both linguistics characteristics of learners (e.g. proficiency) and other aspects (e.g. age and motivation); (3) Meaning focus. It depicts the communicative approach which aims to focus on meaning rather in form; (4) Authenticity. It comes to the question to what degree the materials provide learner into real-world situation; and (5) Impact. It focuses on how far the multimedia resources affect learners' motivation, interest, and engagement during the learning process. In overall, every CALL evaluation should be related to the instructed SLA theory and research, not only being judgmental evaluation but also empirical evaluation.

Table 1: Overview of Some Selected Frameworks related to Computer-assisted Language Learning (CALL) and Website Evaluation

\begin{tabular}{|c|c|c|c|}
\hline Framework & & Evaluation Criteria & $\begin{array}{l}\text { Evaluation } \\
\text { Perspective }\end{array}$ \\
\hline $\begin{array}{l}\text { Hadjerrout } \\
(2010)\end{array}$ & $\begin{array}{l}\text { 1) } \\
\text { 2) }\end{array}$ & $\begin{array}{l}\text { Technical usability. It consists of content design, } \\
\text { page design, and site design; and } \\
\text { Pedagogical usability. It covers understandability, } \\
\text { added value, learning goal, time, interactivity, } \\
\text { multimedia, motivation, flexibility, autonomy, } \\
\text { collaboration, and media variation. }\end{array}$ & $\begin{array}{l}\text { Web designer, } \\
\text { teacher and } \\
\text { learner. }\end{array}$ \\
\hline $\begin{array}{l}\text { Burston } \\
(2003) \text { and } \\
\text { Hubbard } \\
(2006)\end{array}$ & $\begin{array}{l}\text { 1) } \\
\text { 2) } \\
\text { 3) } \\
\text { 4) } \\
\text { 5) }\end{array}$ & $\begin{array}{l}\text { technical preview, } \\
\text { operational description, } \\
\text { teacher fit and learner fit } \\
\text { implementation schemes, and } \\
\text { appropriateness judgment. }\end{array}$ & Teacher \\
\hline
\end{tabular}




\begin{tabular}{lll} 
Chapelle & 1) language-learning potential, & SLA researcher, \\
$(2008)$ & 2) learner fit, & CALL \\
& 3) meaning focus, & developer, \\
4) authenticity & teacher and \\
5) positive impact, and & learner. \\
6) practicality. & \\
\hline
\end{tabular}

\section{CALL Software Evaluation toward Web-based Resources for Teaching Listening: A Proposed Framework}

Obviously, website evaluation is not only a matter of judging its general layout but also looking to those features that promote language learning. In this article, the evaluation is conducted as a guidance for teachers in doing website materials evaluation in order to provide proper materials for teaching listening. As a consequence, there will be three proposed stages in doing the evaluation adapted from the previous frameworks. First of all, reviewing technical usability covers the evaluation of content, page and site design. Content evaluation can be done through checking how easy to read the content of the web and how efficient it is to access it. Meanwhile, page design is related to the use of multimedia, logo, illustrations on the website and site design cover how easy it is to access the menus and links. Secondly, describing the functionality in assisting language learning (based on SLA and pedagogical approaches) includes evaluating learning materials (e.g. the subject matter, its content, topic and subtopic, assignment, learning objectives related to the content, and required skills), activity procedures (e.g. the sequence of pre, whilst- and post listening, and indication of bottom and top-down listening process), language-learning potential (the degree of opportunity for focusing of form), and positive impact (psychological features, e.g. motivation and level of anxiety). Lastly, judging websites appropriateness includes the predictive evaluation in using the websites as the listening teaching materials in a classroom addresses to teachers.

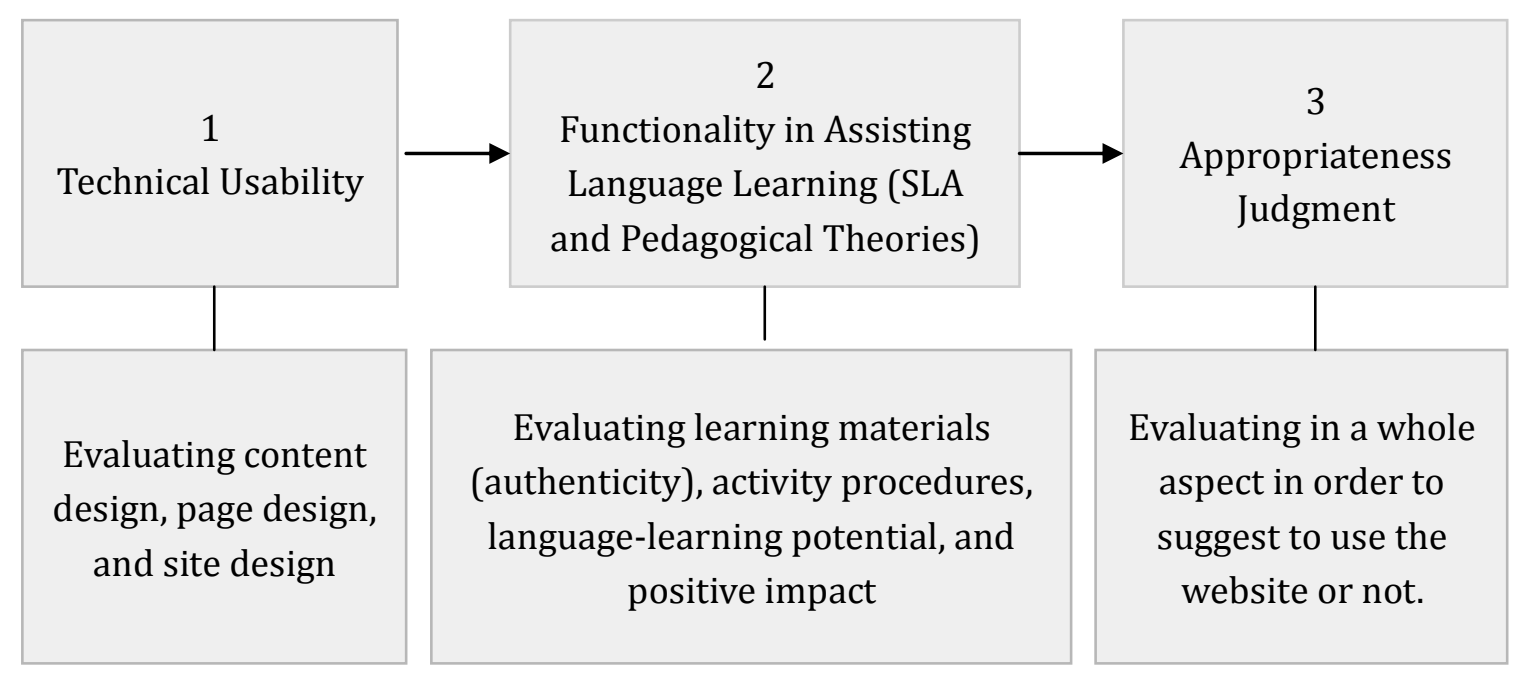


CALL and SLA Theory: Developing A Framework to Analyze Web-based Materials for Teaching Listening Skills

Figure 1. The Proposed Evaluation Framework for Web-based Listening Materials

\section{Exemplary of Web-based Learning Resources for Teaching Listening Skills}

As an example of performing CALL software evaluation, two websites regarding for teaching listening are selected based on several reasons: (1) the site is free and open access; (2) the materials are always updated; and (3) websites are concerned on the learning and teaching of ESL/EFL, especially listening.

\section{Evaluation on "Randall's ESL Cyber Listening Lab"}

To begin with, in term of technical usability, the website is easy to be accessed and requires no subscription. The content of materials is organized wells in several menu buttons and links. Moreover, the clear logo makes the user easy to operate the website. However, there are two spots of commercial advertisement with relatively eye-catching that it is assumed distracting user to get into the exercises.

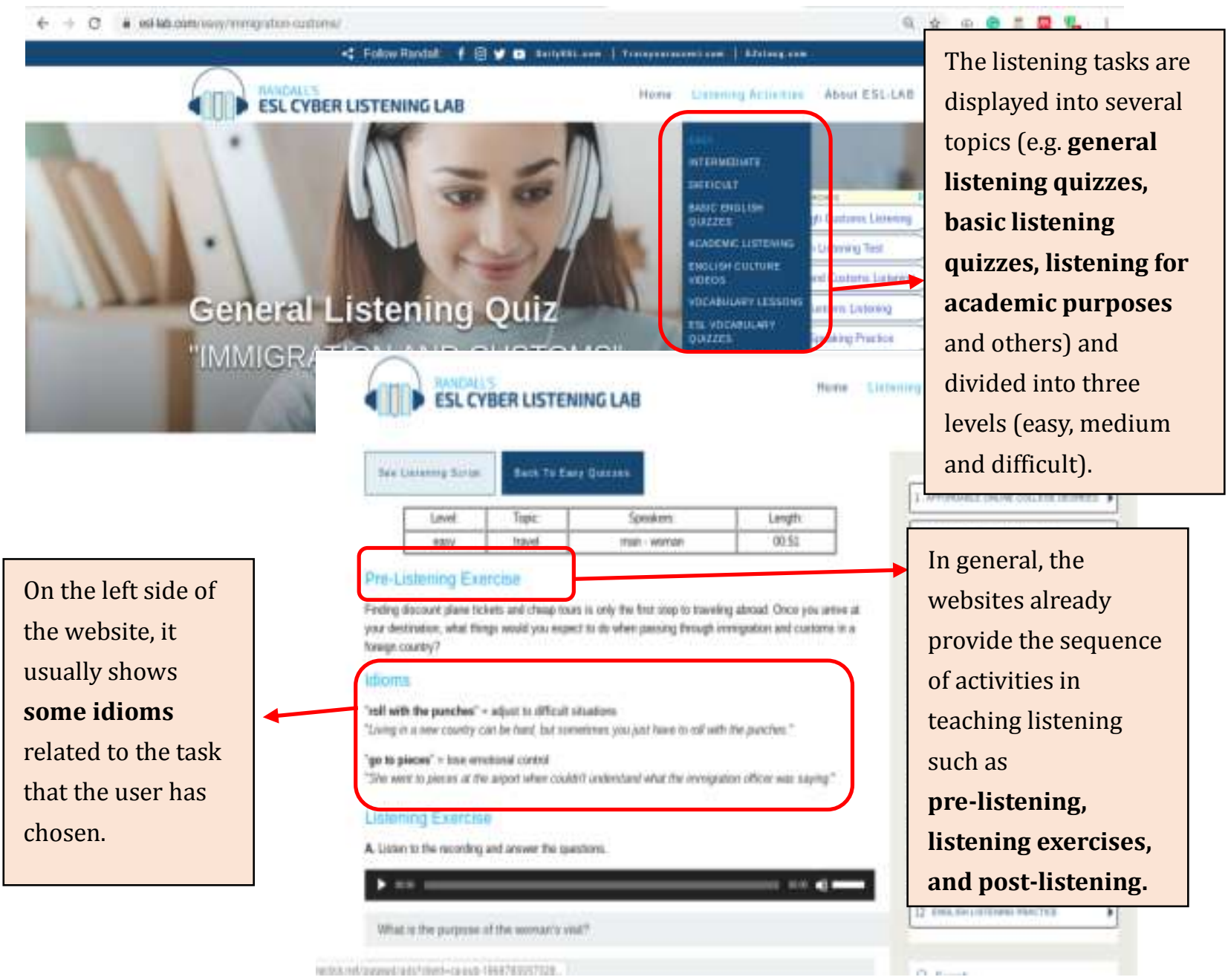

Figure 2. An Exemplary display of "Randall's ESL Cyber Listening Lab" (http://esl-lab.com/) 
There are some potentials of readily used materials provided with the regards of functionality in assisting the language learning, especially listening. The listening materials are divided based on the function of the task such as general listening quizzes (the listening topics are closely related to the everyday conversations), basic listening quizzes, listening quizzes for academic purposes (it includes lectures, interviews, and conversation for preparing listening tests), 20-minutes ESL vocabulary lessons (it provides some drillings on vocabulary and pronunciation) and language learning and life tips. The main exercises are displayed on the website with the clicking button to the answer, and the result is directly showed in the final score column along with the correct answers as explicit feedback. The listening activities are designed based on the pedagogical approach namely pre-listening, exercises, and post-listening. Some questions are addressed in pre-listening in order to build learners' schemata or background knowledge related to the topic. The additional activities are focused in two components namely vocabulary (it has several exercises such as mixed-up sentence, multiple-choice, short-answer questions, and vocabulary matching), and grammar. These additional exercises enable learners to learn more about the input they get from the listening activities. Further, online investigations activity allows learners to explore more input and knowledge about the topic discussed and stimulate learners to have independent learning. On the left side of the website, there is an additional column about idioms. This display also considered as a good input since it highlights new idioms related to the topic and provides some examples in sentences. Lastly, similar with pre-listening activities, post-listening activity plays as follow-up activities ranging including answering questions individually or making group discussion in order to have speaking or writing activities.

In relation to judging the appropriateness as listening materials, the website is basically good for teaching listening in one computer classroom setting. The listening activities have been designed based on pedagogical reason (pre-listening, exercises and post-listening) and graded into some levels (e.g. easy, medium and difficult). It also provides additional components including grammar and vocabulary. However, most of the topics have limited number of activities. Hence, it will seem boring and uninteresting activity for learners if teachers do not have creativity to develop the materials or activities. Moreover, teachers should pay attention to the advertisement displayed that might distract learners' attention to the lesson. Lastly, analyzing the listening audio materials, even the listening audio is recorded, yet it is categorized as authentic materials since the conversations between the speakers employing a variation of speed, natural intonation, incomplete utterances, colloquial language, variety of accents, and background noise present.

\section{Evaluation on "Breaking News English"}

In overall, in term of technical usability, the display including interface, 
Khoiriyah Khoiriyah

CALL and SLA Theory: Developing A Framework to Analyze Web-based Materials for Teaching Listening Skills

navigation and directions to other menus are immensely clear although some spots are available for commercial advertisement. The listening materials are designed with hundreds of alternative activities, including other skills (reading, speaking and writing) and components (spelling, pronunciation and vocabulary).

Referring functionality in assisting the language learning, the website provides sequenced teaching and learning activities, namely pre-listening, exercises and post-listening. In pre-listening, it provides more varieties of activities compared to the previous website such as warm-up activity, pair discussion, true and false questions regarding the topic and many more. However, all exercises are not displayed on the website and there is no feedback from the website to check the learners' answer, so teachers can not directly show it to learners. Hence, teachers should print the materials beforehand. Yet, the website provides many ready-use English lessons with graded level 0 until level 6 and also in five different speed of listening input. These materials can be adopted by teachers that fit with the learners' level of ability. For post-listening activities, it can be designed in many various activities such as reading through using true and false questions, speaking through discussion and role-play, writing through constructing an opinion paragraph, or even vocabulary building. Those exercises allow learners to have more opportunity to deal with the aural input and activate their learning strategies as well.
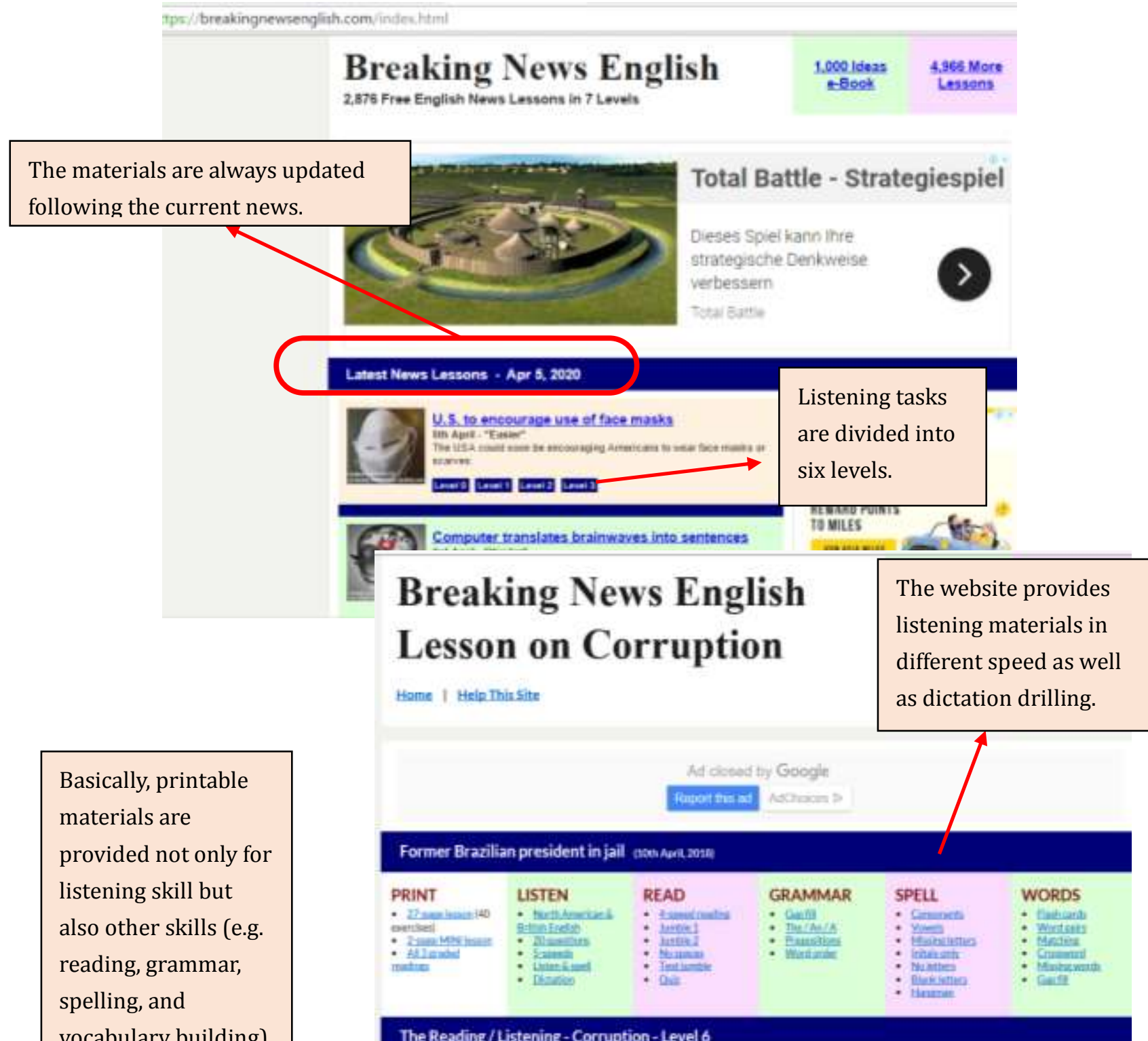


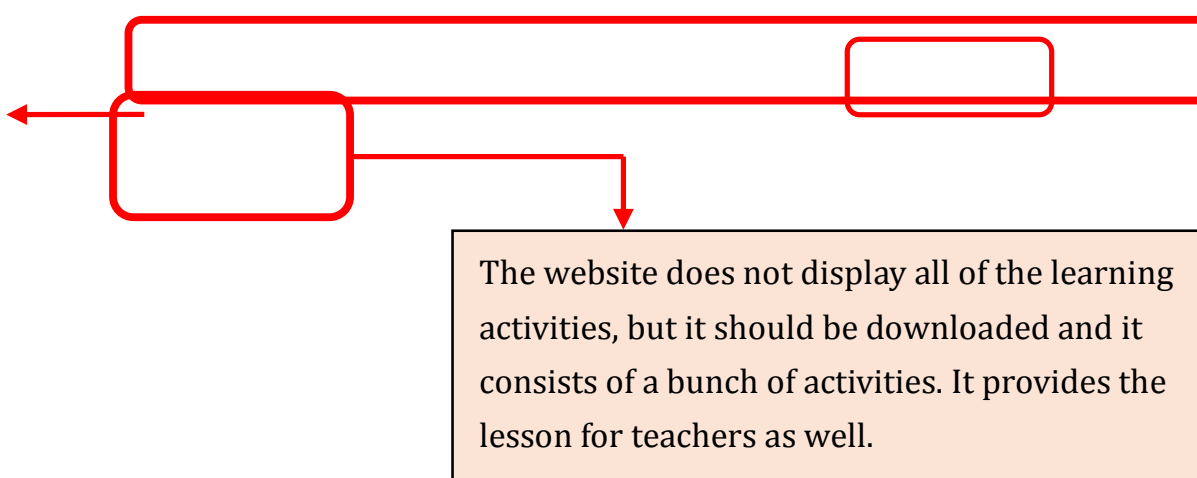

Figure 3. An Exemplary Display of "Breaking News English" (https://breakingnewsenglish.com)

Subsequently, the last consideration is appropriateness judgment. the website will be beneficial for teacher to teach listening since it provides hundreds reproducible activities for teaching listening in one computer classroom. Moreover, the listening aural input also provides authentic texts compiled from various news websites. Further, the aural input is considered as authentic input since it is also differentiated into two accents, namely British English and American English. It fits for learners with a wide range of ability starting from beginner to advanced learners. Lastly, the website also provides alternative mini lessons within the time constrains of class is suitable for learners to finish the listening section for one sitting classroom. Nonetheless, the preparation is still need to be done by teacher since all the materials are only in printable form and there is no program to assess the learner's progress.

\section{Conclusion}

Listening skills are particularly difficult to teach and to master. Yet, a good material and methodology will immensely important to create an effective teaching and learning process. Throughout this article, a framework is proposed in selecting the proper website based on CALL and SLA theories; including technical usability, functionality in assisting language learning, and appropriateness judgement. This article is projected to help teachers to review the proper website-based listening materials for their particular learners, purposes and teaching methodology. Hence, teachers enable to facilitate an effective learning process, especially for listening skills.

\section{References}

Al-azzemy, A. F. T., \& Al-jamal, D. A. H. (2019). Evaluating cognitive , metacognitive and social listening comprehension teaching strategies in Kuwaiti classrooms. Heliyon, June 2018, e01264. https://doi.org/10.1016/j.heliyon.2019.e01264 Aryanaa, Suhud \& Apasari, Y. (2018). Analyzing Teacher's Difficulties in Teaching 
Khoiriyah Khoiriyah

CALL and SLA Theory: Developing A Framework to Analyze Web-based Materials for Teaching Listening Skills

Listening. ELTIN Journal, 6(II), 100-106.

Chao, L. I. (2013). The Influence of Krashen 's Input Hypothesis on Teaching College

English Listening in China. 6(3), 49-52.

https://doi.org/10.3968/j.sll.1923156320130603.5271

Chapelle, C. A., \& Hall, R. (2009). The Relationship Between Second Language Acquisition Theory and Computer-Assisted Language Learning. The Modern Language Journal, 93, 741-753.

Demissie, A. (2019). An Evaluation of the Listening Task Presented in Grade 9 English Textbook and Their Actual Classroom Implementation with Special Reference to Ethio-Parents' Secondary and Preparatory private School. $M A$ Thesis in Teching English as a Foreign Language (TEFL), Addis Ababa University. Du, J. (2019). Application of Schema Theory in College English Listening Teaching. Advances in Social Science, Education and Humanities Research, 336, 729-733.

Egbert, J. O. Y. (2018). CALL ( Computer-Assisted Language Learning ) Methodology. The TESOL Encyclopedia of English Language Teaching, 1(I), 1-6. https://doi.org/10.1002/9781118784235.eelt0393

Emerick, M. R. (2018). Explicit teaching and authenticity in L2 listening instruction: University language teachers' beliefs. System. https://doi.org/10.1016/j.system.2018.11.004

Felix, U., \& Felix, U. (2007). Analysing Recent CALL Effectiveness Research Towards a Common Agenda Analysing Recent CALL Effectiveness Research Towards a Common Agenda (Issue April 2013). https://doi.org/10.1080/09588220500132274

Gaber, M. E.-D. (2015). Utilizing Mobile Assisted Language Learning ( MALL ) to Develop EFL Listening Skills and Learner Autonomy Mohamed El-Desouky Gaber. Faculty of Education Mansoura University Journal. https://doi.org/10.13140/RG.2.2.34037.88805

Gilakjani, A. P., \& Sabouri, N. B. (2016a). Learners 'Listening Comprehension Difficulties in English Language Learning: A Literature Review. 9(6), 123-133. https://doi.org/10.5539/elt.v9n6p123

Gilakjani, A. P., \& Sabouri, N. B. (2016b). The Significance of Listening Comprehension in English Language Teaching. Theory and Practice in Language Studies, 6(8), 1670-1677.

Golonka, E. M., Bowles, A. R., Frank, V. M., Richardson, D. L., \& Freynik, S. (2014). Technologies for foreign language learning: A review of technology types and their effectiveness. Computer Assisted Language Learning, 27(1), 70-105. https://doi.org/10.1080/09588221.2012.700315

Hamouda, A. (2013). An Investigation of Listening Comprehension Problems Encountered by Saudi Students in the EL Listening Classroom. International Journal of Academic Research in Progressive Education and Development, 2(2), 113-155.

Hanbi, J. (2019). Evaluation of the Korean Middle School English Textbook : Listening Skill. 7(2), 228-235. https://doi.org/10.9744/katakita.7.2.228-235 
Hellmich, E. A. (2019). CALL Beliefs in Context: a Study of US High School Foreign Language Learners. Computer Assisted Language Learning, 0(0), 1-23. https://doi.org/10.1080/09588221.2019.1643739

Henrichsen, L., Blanco, K. D., Carreño, S., \& Carter, S. (2018). Online resources for learners and teachers of English language pronunciation. TESL Reporter, 1(July), 23-89.

Hubbard, P. (2006). Evaluating CALL Software. Calling on CALL: From Theory and Research to New Directions in Foreign Language Teaching, Chapter 13, 1-26.

Krashen, S. D. (1984). Krashen (1984).pdf. A Theoretical Basis for Teaching the Receptive Skills, 4, 261.

Milliner, B. (2018). Five Online Resources for Extensive Listening in the Japanese EFL Classroom. Accents Asia, 9(January), 1-10.

Mohamed Fauzi, S. S., \& Raja Hussain, R. M. (2016). Designing Instruction for Active and Reflective Learners in the Flipped Classroom. Malaysian Journal of Learning and Instruction, 13(Vol. 13, No. 2 Dec 2016), 147-173. https://doi.org/10.32890/mjli2016.13.2.6

Naely, M., Alimin, L., Shanty, H., \& Khairun, N. (2018). USING YOUTUBE AS UNLIMITED EDUCATIONAL VIDEO RESOURCES IN TEACHING ENGLISH SKILLS. IDEAS: Journal on English Language Teaching and Learning, Linguistics and Literature, 3(2). doi:https://doi.org/10.24256/ideas.v3i2.145

Namaziandost, E., Branch, S., \& Nasri, M. (2019). The Impact of Using Audio-Visual Aids on Teaching Listening Among Iranian Pre-Intermediate EFL Learners. October.

Nunan, D. (1998). Approaches to Teaching Listening in the Language Classroom. Proceedings of the 1997 Korea TESOL Conference, January, 1-8.

Okonkwo, U. C. (2011). Computer Assisted Language Learning (CALL) Software: Evaluation of its Influence in a Language Learning Process Ugochukwu C. Okonkwo. UJAH: Unizik Journal of Arts and Humanities Is, 76-89.

Pekel, A. (2019). Turkish EFL Sttudents' Academic Listening Comprehension Problems. Master Thesis, Department of Foreign Language Education, Marmara University.

Sukmawati, P. T., \& Eka, M. (2018). LISTEN ENGLISH FULL AUDIO as a SUPPORTING MEDIA in IMPROVING STUDENTS' LISTENING SKILL. IDEAS: Journal on English Language Teaching and Learning, Linguistics and Literature, 6(2), 1-8. https://doi.org/10.24256/ideas.v6i2.507

Tafazoli, D., \& Golshan, N. (2014). Review of computer-assisted language learning: History , merits \& barriers. International Journal of Language and Linguistics, 2(September), 32-38. https://doi.org/10.11648/j.ijll.s.2014020501.15

Takaesu, A. (2013). Teaching Practice TED Talks as an Extensive Listening Resource for EAP Students. Language Education in Asia, 4(2), 150-162.

Vandergrift, L., \& Goh, C. C. M. (2012). Teaching and Learning Second Language Listening. 
Khoiriyah Khoiriyah

CALL and SLA Theory: Developing A Framework to Analyze Web-based Materials for Teaching Listening Skills

Xie, H. (2018). Teaching Practice of News English Listening Based on Digital Resources Huiying Xie. Advances in Social Science, Education and Humanities Research, 120, 141-146.

\section{Suggested Web-based Materials for Listening Skills}

1. SwiftScribe - https://swiftscribe.ai/

2. YouTube Kids - https://kids.youtube.com/

3. CNN Student - http://edition.cnn.com/studentnews

4. Lyricstraining - http://lyricstraining.com/

5. $\quad$ English Listening Lesson Library Online - http://www.elllo.org/

6. TED - https://www.ted.com/

7. EngVid, Free English Video Lesson - https://www.engvid.com/

8. $\quad$ Listening British Council -

https://learnenglish.britishcouncil.org/skills/listening 